\title{
Rusya Türklerinin ve Müslümanlarının Milli ve Medeni Bilinçlenmelerinde Tercüman Gazetesinin Rolü
}

\begin{abstract}
Taybe Topsakal*
Uşak Üniversitesi, İletişim Fakültesi, Uşak.

$\ddot{O} z$

İsmail Gaspıral ve kendisinin neşrettiği Tercüman Gazetesi, Rusya Müslümanlarının milli ve medeni seviyelerinin yükselmesinde, eğitimin Avrupa tarzında yapılmasında, kadınların eğitim ve haklarının ilerlemesinde, dini kurumlarm düzenlenmesinde, bütün Türkleri birleştirebilecek ortak bir Türkçenin oluşabilmesinde büyük çabalar sarf etmiş ve mücadele etmiştir. Tercüman Gazetesi, Rusya Türkleri ve Müslümanları açısından Rusya içinde en uzun yayın hayatında kalabilen, halkı aydınlatan, halkı köhne düşüncelerden arındırmayı amaç edinen ve cahilliğe karşı savaş açan çok önemli bir gazetedir. Ismail Gaspıralı dilde, fikirde, işte birlik idealini gerçekleştirmek amacıyla Tercüman Gazetesi'nde yazılar ve makaleler yayımlanmıştır. Özellikle eğitim meselesi, kız çocuklarının eğitimi gibi konular gazetede sıkça yer almıştır. Eğitimde eski usullerden yeni usullere geçilerek daha kolay okuma ve yazmanın öğrenilmesini sağlamak amacıyla Tercüman Gazetesi halkı bilinçlendirmede ve aydınlatmada büyük katkılar sağlamıştır. Ayrıca gazetede Osmanlı Devletiyle ilgili de birçok makale ve yazı da neşredilmiştir. İsmail Gaspıralı Rusya Müslümanları için Osmanlı Devletini örnek almıştır. Çünkü o dönemde Müslümanlar arasında medeni ve birçok konuda en ileride olan devlet Osmanlı Devleti idi. Bu makale öncelikle Tercüman Gazetesini neşreden İsmail Gaspıralı ile ilgili bilgi vermekle başlamakta, Tercüman Gazetesi hakkında ayrmntıl bilgiler vererek devam etmektedir. Daha sonra Tercüman Gazetesi'nin bölümleri ve içeriğiyle ilgili bilgi verilmekte, çalışma Tercüman Gazetesi'nin amacı, dili, eğitime verdiği önem, gazetede yer alan yazı ve makalelerden örneklerle son bulmaktadir.
\end{abstract}

Anahtar Kelimeler: İsmail Gaspıral, Tercüman Gazetesi, Ortak Türkçe, Ceditçilik

\section{The Role of the Tercüman Newspaper in the National and Civil Awareness of Russian Turks and Muslims}

\section{Abstract}

Ismail Gaspiral and the Tercüman Newspaper which he distributed made a great effort and struggle to raise the national and civilian levels of the Muslims of Russia, to make the education in the European style, to advance the education and rights of women, to organize the religious institutions, to form a common Turkish that could unite all the Turks. Tercüman Newspaper is a very important newspaper in Russia for the Turks and Muslims of Russia, which can stay in the longest broadcasting life, enlighten the people, aims to purge the people from the old ideas and wages ignorance. Ismail Gaspiral has published essays and articles in Tercüman Newspaper in order to realize the ideal of unity in language, opinion and work. Issues such as education, girls' education, etc. were frequently included in the newspaper. Tercüman Newspaper has made great contributions to raising public awareness and enlightenment in order to aim at learning how to read and write more easily by shifting new methods in education. In addition, many papers and articles related to the Ottoman Empire were published in newspapers. Ismail Gaspiral took the Ottoman State as an example for the Muslims of Russia. Because, at that time, the Ottoman state was the most advanced state among many Muslim communities. This article begins with giving information about Ismail Gaspiral, who disseminates the Tercüman 
newspaper, and gives detailed information about Tercüman Newspaper. Afterwards, information about the sections and the contents of the Tercüman Newspaper is given and the study ends with the aim of the Tercüman Newspaper, its language, the importance it attaches to education, and the articles in the newspaper.

Keywords: İsmail Gaspırah, Tercüman Newspaper, Common Turkish, Ceditçilik

\section{GİRIŞ}

İsmail Gaspıralı çıkardığı Tercüman Gazetesi ile Rusya Türklerinin ve Müslümanlarının aydınlanması, eğitilmesi için çabalar sarf etmiştir. Gazetede eğitim ve dil konuları üzerinde önemle durularak, halkın daha iyi bir eğitim alması ve medeni yaşam koşullarına ulaşması için yazı ve makaleler kaleme alınmıştır. Medeni ve ileri bir seviyeye ulaşmak için eğitim konusuna çok vererek kız çocuklarının da eğitim hakkı olduğunu savunmuştur. İsmail Gaspıralı, ortak Türkçe ile Türk dünyasını birleştiren bir dil olması gerektiğine inanmıştır. Bu ideali için de çıkardığı Tercüman Gazetesi ile birlikte mücadele vermiştir. Tercüman Gazetesi, yeniliklere açık bir tavır sergileyerek milli bir duruş sergilemiştir.

O dönemin içinde bulunduğu şartlar düşünüldügünde, özellikle Rus Hükümetinin baskıcı tavrı sebebiyle özgür bir basından söz etmek mümkün değil idi. Rus Hükümeti ile ters düşmemek adına İsmail Gaspıralı, Tercüman Gazetesi'nin üslubunu çok dikkatli ve üstü örtülü kullanarak uzun süre yayın hayatında kalmayı başarmıştır. Tercüman dışında diğer gazeteler Rus hükümeti tarafından kapatılmıştır. Tercüman izlediği yumuşak ve uyumlu bir tavır ile Rus hükümetiyle ters düşmeme konusunda oldukça ihtiyatlı bir tavır sergilemiştir. İsmail Gaspıralı çok zor şartlar altında çıkardığı Tercüman Gazetesi konusunda Rus Hükümeti ile uğraşmak zorunda kalmıştır. Gaspıralı'nın çok zor şartlarda çıkardığı Tercüman Gazetesi halkı aydınlatma ve bilinçlendirmede çok büyük katkılar sağlayarak Rusya Müslümanlarının adeta simgesi olmuştur.

\section{2. İSMAIIL GASPIRALI ve TERCÜMAN GAZETESİ}

Kazan Türklerinin milli uyanışında ve medeniyet seviyesinin yükselmesinde büyük katkıları olan İsmail Gaspıralı 1851 yılında Kırım'ın Bahçesaray şehri yakınlarındaki Avcıköy'de dünyaya gelmiştir. Annesi Fatme Sultan köklü bir mirza ailesinden gelirken babası Mustafa Ağa, Gaspıra köyünden geldiği için İsmail Bey de Gaspıralı lakabıyla tanınmıştır. Mustafa Ağa aydın ve vatansever bir insandı ve kendisi Çarlık ordusunda görev yapmıştır(Yaman, 2002: 22).

10 yaşına kadar Bahçesaray'da kalan Gaspıralı ilköğrenimini burada görmüştür. Tahsil hayatına Mahalli Müslüman mektebinde başlamış ve bir Rus Okulu olan Akmescit Erkek Gimnazyumu'nda sürdürmüştür. Daha sonra ise Moskova'da bulunan Harp Okuluna kaydolmuştur. O yıllarda askeri lisede okuyan öğrencilere "Türk düşmanlı̆̆ı" ve "Slav Birliği" doğrultusunda eğitim verilmekteydi. Bu durum İsmail Gaspıralıyı etkileyerek kendi milletine olan bağlılığını daha da pekiştirmiştir. İsmail Gaspıralı baskılar altında yetişmesinin verdiği psikolojiyle bütün Türklerini birliğini düşünen bir milliyetçiliği benimsemiştir.1874'te Osmanlı zabiti olmak için 
İstanbul'a gelen Gaspıralı müracaatına olumlu karşılık alamayarak tekrar Kırım'a dönmüştür(Yaman, 2002: 22-23).

İsmail Gaspıralının milli bir duruş sergileyerek kendi dil ve inançlarına bağlı kalması, başka bir devletin hakimiyeti altında zor şartlarda ve baskı görerek kalmasının bir sonucudur.O dönemde Rus hükümetinin Türk düşmanlığ asimilasyon çabaları Gaspıralı'nın kendi milli değer ve inanışlarına bağlı kalma duygularını daha da pekiştirmiştir.

1875-1881 yılları arasında Bahçesaray'da ilkokul öğretmeni ve belediye başkanı olarak çalıştı.1879'da gazete çıkarmak istedi fakat izin alamadı.1881'de Tavrida Gazetesinde Rusça olarak yayımlanan makalesinde kendi programını ilan etti. Bu program, eğitimde reform yapılması, milli eğitimin maddi olarak desteklenmesi için "Cemiyet-i Hayriye"lerin kurulması, ortak dilde milli basının faaliyete geçmesi, hayat tarzının modernleşmesi, Müslüman kadının hürriyete kavuşturulması, milli aydınlar zümresinin yetiştirilmesi gibi konuları kapsamaktaydı (Devlet, 1999: 17-18).

Dilde, fikirde, işte birlik düşüncesiyle bütün Türklerin ortak bir Türk dilini oluşturmak istemiştir. Yeni ve modern hayat tarzının önemine vurgu yaparak Rusya Müslümanlarının diğer medeni ülkeler seviyesine yükselmesini istemiştir. Özellikle eğitim alanında yeni reformlarla Rusya Türklerine çağdaş bir yaşam seviyesine yükselme olanağı sunmuştur. Kız çocuklarına erkek çocukları gibi okuma yazma olanağının verilmesini sağlamıştır. Önderi olduğu Ceditçilik Hareketiyle Rusya Türklerinin aydınlanmasında büyük katkılara sahiptir. İdeallerini ve görüşlerini halka sunmak için Tercüman Gazetesini çıkarmıştır. İsmail Gaspıralı Türkçülük hareketini benimseyerek bu doğrultuda ve halkın aydınlatılmasında Tercüman Gazetesinde pek çok yazı yazmıştır.

İsmail Gaspıralı Petesburg'a yaptığı ziyaretler ile birlikte Tercüman Gazetesini çıkarmak ve matbaa kurmak için Rus yetkililerinden gerekli izni almıştı. Gazete Türkçe ve Rusça iki bölümden oluşacaktı. Rus Hükümetinin bu izni vermesinde yerli Müslüman halkın Rusya'ya sempati duymasını sağlamak olduğu düşünülmüştür. Ayrıca Gaspıralı'nın Bahçesaray Belediye başkanı olması, Rus ileri gelenleriyle dostane ilişkileri, Rus okullarında eğitim görmesi gibi unsurlar gazete çıkarmak için izin almasında büyük rol oynamıştır. Tercüman Gazetesi 10 Nisan 1883 tarihinde yayın hayatına başladı. Gaspıralı gazetenin yayılabilmesi için rejime uyumlu davranmak zorundaydı. Bu nedenle kendi fikirlerini yumuşak, üstü örtülü biçimde anlatmak ve Rus hükümetini kızdırmamak zorundaydı. Bu politikasından dolayı Tercüman Gazetesi diğer Türk gazeteleri içinde en uzun süre yayın hayatında kalmayı başarmıştır (Devlet, 2011: 73-75).

İsmail Gaspıralı, Tercüman Gazetesinin o dönemin Rus hükümeti ile uyumlu ve dengeli davranarak uzun süre yayın hayatında kalmasını sağlamıştır. Rus hükümetine karşı ve muhalif bir tavır sergilese idi kısa sürede gazetenin kapanmasına neden olabilecekti. Fakat Gaspıralı iyi bir denge politikası izleyerek Tercüman Gazetesi'nden Rusya Türklerinin uzun süre faydalanmasını sağladı. 
İsmail Gaspıralı hem Ruslardan hem de Müslümanlardan tepki almamak için tedbirli davranmak durumunda kalmıştır. “Tercüman/Perevotçik'in sayfalarında yayımlanan tenkitler hakaret ve adi dedikodular olarak yorumlanıyor ve Gaspıralı'nın Ruslara kültürel yönden yaklaşma teklifleri şüphe ile karşılanıyordu. Gaspıralı ilk yıllarda okuyucuyu ürkütmemek için aşırı temkinli davrandı. Gazetede Müslüman okuyucuları rahatsız etmeyecek, huzurunu bozmayacak tarafsız bilgiler verilmeye dikkat edildi"(Devlet, 2011: 82).

Adını İstanbul'da Şinasi Efendi'nin çıkardı̆̆ı Tercüman-ı Ahval'den alan gazete Rusya'da yayımlanan ilk Türk gazetesi olmamakla birlikte oynadığı rol bakımında en başta gelmekte idi. 10 Nisan 1883'ten 1918'e kadar (1903'e kadar haftada bir, 1903-1912 arasında bazen iki, bazen üç defa, Eylül 1912' den sonra günlük olarak ) 35 yıl yayına devam eden Tercüman Gazetesi Kahire'den Kaşgar'a Kazan'dan Hindistan'a kadar yayılıyordu. Ayrıca Osmanlı ülkesinde de takip edilen bir gazete idi (Devlet, 1999: 18).

Başarılı bir yayın politikası izleyen gazete, birçok bölgeye de ulaşmış ve okunmuştur. Gazetenin Osmanlı Devleti'nde de okunuyor olması, Rusya Türklerinin sesini Osmanlı Devleti'ne ve diğer ülkelere ulaştırması bakımından önemlidir. Fakat Tercüman Gazetesi'nin maruz kaldığı baskılar nedeniyle de gerçekleri tam olarak açıklayamıyor olması da basın üzerinde baskıların yoğun biçimde olduğunu göstermektedir.

Gaspıralı, Rusya'da Usul-ü Cedit ile Türk okullarını matematikle, bilimle, Türk dili ile buluşturdu ve baskıları gögüüsledi. Anadolu'da da bu hareketin halkın kararlılığı ile uygulanacağına inanıyordu (Turhan, 2013: 53). Yenilikçi hareketler o dönemde Gaspıralı'yı son derece etkilemişti. İsmail Gaspıralı, milletlerin geri kalmışlığının yeni ve modern bir bakış açısı ile ortak dil ve düşüncede birleşerek yenilikçi bir eğitim anlayışı ile bertaraf edilebileceğini düşünmekteydi.

“Gaspıralı, Tercüman'ın ilk sayılarında Rusya'da İslamiyetin modernleştirilmesini, Müslüman dünyasında kadınlara eşitlik tanınmasını, basında kullanılacak tek bir Türk yazı dili yaratılmasını ve böylece Rusya ve Osmanlı İmparatorluğu'nda Türkleri birleştirecek tek bir münevver Türk zümresinin tesisini talep ediyordu"(Aktaran Fisher, 2009: 148-149).

İsmail Gaspıralı bir çok alanda yenilikçi bir bakış açısını benimsedi. Modern bir bakış açısına sahip olan Gaspıralı, kadınların da modern dünyada eşit olması gerektiğini düşünerek onların haklarını savunmuş ve eğitimleri için çaba sarfetmiştir. Türklerin farklı yerlerde farklı dil ve lehçe ile konuşmaları onların birleşimini olumsuz etkileyeceğini düşünerek tek ortak bir Türkçe olması gerektiğini düşündü. İsmail Gaspıralı, benimsediği bu yenilikçi yaklaşım ile bir çok kişiyi etkiledi. Bunlardan biri de Yusuf Akçura idi.

Akçura ve Gaspıralı pek çok konuda aynı fikirleri paylaşıyorlardı. Yusuf Akçura; Türklerin birliğin sağlama, kültürel alanda mücadele etme ve ilerleme sürecinde kadının yerinin önemi ve laik düşünce yapısına ulaşma gibi konulardaki fikirlerinde Gaspıralı'dan etkilendi (Georgeon, 2005: 26-27). Gaspıralı, yenilikçi ve 
modern bakış açısı ile birçok kişi için ilham kaynağı olmuştur. Rusya Türkleri için de önemli ve reformist bir kişi olmuştur.

Tercüman Gazetesi'nin tiraj bilgilerine bakacak olursak, “Tercüman'ın ilk çıktığ1 zaman 320 alıcısı vardı. 1884'te bu 406'ya çıtı. 1885 te ise 1000'i geçti. Tercüman alıcılarından 300'ü Kırımlı, 300'ü Astırahan, Samara, saratof, Orenburg, Ufa Kazan ve Perm Müslümanları, 150'si Dağıstanlılar, 50'si Sibirya Müslümanları, 200'ü Ortaasya ve Türkistan Müslümanlarıdır. Bunlar arasında alimler, tüccarlar, mirzalar, köylüler vardır. Bu her cins adamlar karşısında ve her vilayette Tercüman'a rağbet artmaktadır" Tercüman 1885 yıl, numara1 (Seydahmet, 1996: 74). Tercüman Gazetesi'nin 1910 yılı tiraj1 1500 idi (Devlet, 1999: 114).

\section{TERCÜMAN GAZETESI'NIN İÇERÍĞİ ve BÖLÜMLERİ}

Tercüman Gazetesi'nin ilk sayılarında milli şuur, bir devlet içinde çeşitli dil ve dine mensup insanların birlikte yaşamaları, onların arasındaki iktisadi, medeni ilişkileri konu eden makalelere sıkça rastlanmaktadır. Örnek olarak gazetede topraksızlıktan şikâyet ederek Türkiye'ye göçen Kazan Tatarlarıla ilgili üzüntü bildiren haber ve yorumlar yer almıştır. Tercüman Gazetesi kadın hakları konusunda da haberler yapmaktaydı. Gazete, eğitim görmüş Türk kadınlarıyla ilgili haberlere de yer veriyordu. Örnek olarak gazetenin 1892 yılındaki 17. Sayısında Emine Batırş(ina)'nın “Çiçek hastalığı hakkında iki ağız söz" başlıklı mektubu basılmıştı. Gazetenin giriş kısmında gazetenin şu notu dikkati çekmektedir: "Bu muhterem Müslüman kadını Taşkent lisesinde tahsil görmüştür ve kendi bildiklerini halka aktarmak arzusu bizi ziyadesiyle sevindirmektedir" denilmektedir(Devlet, 2011: 8485).

O dönemin şartları düşünüldüğünde Tercüman Gazetesi, kadına ve kadınların eğitimine önem verdiği görülmektedir. Kadınların eğitimi konusuna verdiği desteği de gazetede her fırsatta dile getirmiştir. Kadınların eğitimine verdiği önem de Rusya Türklerinin ve Müslümanlarının medeni bir seviyeye ulaşmaları için önemli bir çabadır.

İsmail Gaspıralı “Tercüman Gazetesi'nin sütunlarında başta Rusya Türk ve Müslümanları olmak üzere Türk Müslüman dünyasına ait en aktüel, siyasi, sosyal, kültürel, milli ve dini problemleri aydınlatmakta idi (Hablemitoğlu, 2006: 69-70). Tercüman Gazetesi, içerik bakımından çok yönlü ve eğitici bilgiler sunarak halkı bilgilendirmek ve eğitmek amaçlı yazılar kaleme almıştır. Bu yazılar, milli bir üslupla ele alınarak Rusya Müslümanlarını ilgilendiren konular üzerinde yoğunlaşmıştır.

Tercüman Gazetesi basit, alelade haberlere ve eğlenceli romanlara yer vermeyerek Rusya Müslümanlarını temsil eden en önemli gazetelerden biri olmuştur ve iz bırakmıştır. Tercüman Gazetesi'nde en baş makaleden en küçük habere hatta ilanlara kadar bütün yazılar Türklük, İslam ile ilgili konu ve kanaatler ile ilgiliydi. Ayrıca İsmail Gaspıralı medeni uyanışa engel olan ulemayı Tercüman'ın her nüshasında, ya da başmakaleleriyle, haberleriyle insafa davet eder ve eleştirirdi. Bir küçük köyde usulü cedit mektebinin açılması, önemsiz bir kasabada bir tiyatro oyunun 
oynanılması veya müsamere verilmesi, küçük bir kitabın neşri ve hatta bir talebenin liseyi ikmali bile Tercüman'da yer alırdı (Seydahmet, 1996: 77-78).

Tercüman Gazetesi, önemsiz ve halkı oyalayıcı bilgi ve haberlere yer vermeyerek eğitici ve öğretici bir gazete olmayı kendine hedef seçtiği görülmektedir. Rusya Türklerinin gelişmesi ve aydınlanması için de gerekli haberlere yer vermiştir. Tiyatro oyununun haber verilmesi gibi haberleri de halkın gelişmesi ve medeni seviyeye ulaşması anlamında anlamlı ve önemlidir.

İsmail Gaspıralı sert sansür uygulamalarından dolayı iç ve dış gelişmeleri aktarmakta dikkatli olmak durumda kalmıştır. Tenkitlerde de yumuşak olmak zorunda kalmıştır. Gaspıralı, Liberal Rus basınının takip ettiği yoldan giderek aktüel konuları dış ülkelerden alınan örneklerle aydınlatmaya çalışıyordu. Böylece ülkedeki zulüm ve baskılar, temel hak ve hukukların ayaklar altına alınması veya basın hürriyeti gibi konular yabancı ülkelerdeki gelişmelerden örnekler verilerek dolaylı biçimde anlatılırdı (Devlet, 2011: 85).

İsmail Gaspıralı hem Müslüman halkın tepkisi hem de Rus Hükümetinin tavrı ve baskıcı tutumundan dolayı Tercüman'da bahsettiği konularda dengeli ve itinalı davranmıştır. Böyle bir tutum sergilememiş olsa idi büyük ihtimalle Tercüman Gazetesi'nin ömrü bu kadar uzun olmayacak ve Rus Hükümetinin kapatma tehlikesiyle karşı karşıya kalacaktı. Gaspıralı'nın denge politikasıyla Tercüman 35 yıl yayın hayatında kalmayı başarmıştır.

Tercüman Gazetesiyle ilgili konulara örnek olarak, 1892 yılındaki ilk sayısında İstanbul mahreçli ve "Seyyah" imzalı haberi verebiliriz. Bu haberde konu Almanya ve uluslararası işçi hareketinin tanınmış isimlerinden Alman millet meclisine çok kez seçilen August Bebel'dir. "Buradaki basının hali kötü diye yazıyor seyyah, onu tek Türk sansürü değil, serbest Avrupa'nın vekilleri de gözetlemekteler." İstanbul Gazetesi Bebel'in bir söylemine yer vermiştir. Bebel'in Alman imparatoru Wilhem militarist nutukları ile halkı telaşlandırmaktadır diye nutkuna yer verilmiştir. Avrupa gazeteleri bundan daha önemli şeyler yazmaktadır. Fakat Türk gazetesinin bu hareketi Alman elçiliğini kızdırdı ve İstanbul gazetesi yayından men edildi (Devlet, 2011: 85-86).

Tercüman'ın Türkçe bölümü Rusça bölümü ile aynı idi. Gazetenin sağ üst köşesinde yer alan sütunlarda şu ifadeler bulunmaktaydı. "Gazete idaresi Bahçesarayda'dır. Derc ve neşir olunmak (yayınlamak) içün ciberilen (için yollanan) kağıt varak yazıcının adresi ve imzası ile olmalı. Bunlar gerek halde kıskalanur (kısaltılır) ve neşr olunmayan halde poçta (posta) ileri geri ciberilmez (yollanmaz)." Gazetenin ilk sayfasının en önemli bölümleri "idareden, Yüzyıl ve "Rusya'da Matbuat1 İslamiye" adlı bölümleridir. Ayrıca, Ahbar-1 Mahalliye (Yerel Haberler), Münacaat (İdareye Mektuptan), Ahbar-1 Dahiliye (İç Haberler), Ahbar-1 Hariciye (Dış Haberler) gibi bölümler de bulunmaktaydı (Devlet, 2011: 75-76).

İdareden bölümünde Müslümanların ihtiyaçlarını Ruslara duyurmakla ilgili yazılar mevcut idi. Bunu yaparken de Ruslarla çatışmaya girmek istemediği ve resmi politikayla uyumlu olduğunu belli ediyordu. İsmail Gaspıralı Çarlık yönetimiyle ters 
düşmemek için Kırım ile ilgili yazılarda gerçekte öyle olmasa da Kırım'ın kendi isteğiyle Rusya'ya katıldığı gibi ifadeleri kullanmak zorunda kalıyordu. Gaspıralı'nın böyle bir ifade kullanması Tercüman Gazetesi'nin kapatılmasını önlemek içindi. Aksi bir tavır almış olsaydı gazete uzun ömürlü olmayacaktı (Devlet, 2011: 77).

Çarlık yönetiminin tavrı ve o dönemin şartları içinde özgür bir basından söz edilemeyeceği görülmektedir. Rusya Türkleri kendi ihtiyaç ve görüşlerini özgür biçimde Tercüman Gazetesinde dile getirememiştir. Getirmiş olsa idi gazete hemen kapatılır ve yayın hayatına devam edemezdi. Oysaki gazete daha özgür bir yayın ortamı bulabilse idi Rusya Türklerinin sorunları ve beklentileri dile getirilmiş olacak ve Çarlık yönetiminden de bu yönde çözüm üretmesi beklenebilecekti.

Tercüman Gazetesi'nin ilk nüshasının ilk sayısında "Rusya'da Matbuat-1 İslamiye" adlı makalesinde Tercüman'dan önce Türkçe olarak değişik gazete ve dergilerin yayınlanmış olduklarının haberi verilmekteydi. Bu gazeteler, Taşkent'te "Türkistan Gazetesi", Hasan Bek Melik(ov) tarafından 1875'te Bakü'de Ekinci adlı gazetenin çıkarıldığı ve kısa ömürlü olduğu, 1879'da Tiflis'te Ünisi-zade tarafından Ziya-i Kafkasya adlı gazete ile Keşkül adlı bir dergidir. Bu makaleyle gazete Rusya'da Türkçe gazetelere ihtiyaç olduğu ve bunun örneklerinin olduğu vurgulanmıştır. Ayrıca gazetenin Ahbar-1 Mahalliye (Yerel Haberler) bölümünde en önemli haber Kırım müftüsü Knez (prens) Ali Bek Hunkal(ov)'un imparatorluğun Moskova'da düzenlenecek taç giyme merasimine katılacağı ile ilgili haberdi (Devlet, 2011: 77-78).

Tercüman'ın makalelerinden anlaşılacağı gibi İsmail Gaspıralı doğrudan Rus hükümetini hedef alan haberlerden kaçındığı ve Rus hükümetiyle uyumlu bir politika izlediği görülmektedir. Kırım müftüsünün Moskova'daki taç giyme merasimine katılacağı haberi de yine Rus hükümetiyle uyumluluk politikasının bir göstergesidir.

\section{TERCÜMAN GAZETESI'NIN AMACI}

İsmail Gaspıralı Türk milletinin bir bütün olduğuna inanıyor lehçe farklılıklarının bu bütünü parçalamaması gerektiğini düşünüyordu. Bu ortak dilin Arapça, Farsça ve yabancı kelimelerden arındırılması gerektiğini, sade bir Türkçe ile konuşulup yazılması gerektiğini savunuyordu. Bunun için Azerbaycan, İdil-Ural ve Türkiye'deki basın ve yazı işleri ile mektuplaşıyordu. Ayrıca İsmail Gaspıralı'nın Tercüman Gazetesi ile yaydığı fikirleri şöyle sıralayabiliriz (Devlet, 2011: 107);

- Okullarda Avrupa tarzında eğitim yapılması,

- Türkler için ortak bir yazı dili meydana getirilmesi,

- Kadınların esaretten kurtarılması,

- Rusya Türklerinin iktisadi hayata katılmaları,

- Dini idarelerin düzeltilmesi,

- Yardımlaşma cemiyetlerinin kurulması (Devlet, 2011: 117).

İsmail Gaspıralı'nın fikirlerinde ve Tercüman'da yaymak istediği en önemli konunun eğitim meselesi olduğunu görüyoruz. Ortak bir edebi dil ile eğitime çok önem vermesi, eğitimin Avrupa tarzında yapılması gerektiği düşünceleri eğitime verdiği önemi vurgulamaktadır. Ayrıca kadınların esaretten kurtarılmasının istenmesi 
de kadın haklarına verilen önemi ve medeni bir seviyeye ulaşma çabaları olarak karşımıza çıkmaktadır. Dini idarelerin de düzeltilmesinin hedeflenmesi dinde yenilik ve gelişmelerin önünün açılmasının amaçlandığını vurgulamaktadır.

Tercüman Gazetesi'nin 1896 senesinin Mart ayının 31 numaralı 13. Nüshasında “Ufada kızlara mahsus Müslüman mektebi ve medresede Rus dili şubesi açıldığ idaremizce iş'ar onuyor" deniliyordu (Seydahmet, 1996: 80). Bu yazıdan kız çocuklarının eğitimine ne kadar önem verildiği ve Rusça öğrenerek Avrupa medeniyetlerine ulaşmanın önemi vurgulanmıştır. Rus dili şubesinin açılması haberi, Rus yönetimi ile ters düşmemek ve uyumlu bir tavır sergilemek adına bir adım olduğunu göstermektedir.

Ayrıca Tercüman'da yardım kuruluşlarının kurulması gerektiğiyle ilgili yazılar da yazılmıştır. Örnek olarak Yine aynı nüshada, "Bizim Rusya'da milletin cemiyeti hayriyeleri vardır. Müslümanların yoktur. Çünkü gerideyiz. Tertip etmiyoruz ve cami merdiveninde bulunan dilenciye peş para vermekle vazifei insaniye eda edilmiş biliyoruz. Yani bizde cemiyeti hayriye ve edebiyelerin vücuda gelmemesi, "hıssiyatı cemiye" peyda eder dereceyi bulamadığımızdandır" (Seydahmet, 1996: 81).

\section{Tercüman Gazetesi'nin Dili ve Ortak Türkçe}

İsmail Gaspıralı dilde, fikirde, işte birlik ülküsünü gerçekleştirmek istiyordu. Ortak bir edebi dil oluşturarak Türkler arasında birlik sağlamak ve bütün Türklerin anlayacağ olması gerektiğini vurguluyordu.

“Tercüman'ın dili çok sadeleştirilmiş Osmanlı lehçesinden ibaretti. Gaspıralı İsmail Bey'in de “Tercüman'ın neşrindeki gayelerinden en önemlisi muhakkak ki, “ ortak edebi dil" ülküsünün gerçekleşmesidir. Gerçekten İsmail Beyin "Tercüman" kadar hiçbir teşebbüs, Türk dili ıslahı ihtiyacını doğurmamıştır"(Caferoğlu, 1933: 167).

İsmail Bey İstanbul'da bulunduğu zamanlarda Osmanlı aydınları arasında Türk dili le ilgili tartışmalardan etkilenmiştir. Türkçe'nin milli bir dil olarak geliştirilmesi ve halkın anlayabileceği şekilde sadeleştirilmesi gerektiğine inanan Osmanlı aydınları ile yakın ilişkiler kurmuştur. Ülkesine döndükten sonra da Kırım Türkçesine de aynı yöntemi uygulamaya başladı. İsmail Bey bütün Türklerin anlayabileceği bir dil geliştirmenin önemini gördü ve bu yönde çalışmalara başladı (Aktaran Kalsın, 2014: 101-102).

İsmail Gaspıralı Tercüman Gazetesi'ni ortak dil ilkesi ekseninde çıkarmaktaydı. Osmanlı Türkçesine sadık kalıyor, fakat bunu yaparken de ağır Arapça ve Farsça tamlamaları kullanmayarak İstanbul neşriyatını bilen aydınların anlayabileceği bir dilde yazıyordu. Fakat 1905 ihtilalinden sonra biraz olsun basın hürriyetine kavuşan değişik Türk boyları arasında bir gazete yayın politikası gerçekleşmiş ve çoğu çıktıkları bölgenin mahalli şivesini kullanmaya başlamışlardı. Çünkü Gaspıralı'nın kullandığı Osmanlıca Türkçesi Kıpçak mensup Kazan Tatar, Başkurt, Nogay, Kazak, Kırgız ve benzerleri için anlaşılması zor oluyordu ve gazeteler okunamıordu. Bu durum Gaspıralı tarafından ortak dilden ayrılma şeklinde yorumlanıyordu. Bu endişeden 
dolayı Gaspıralı Tercüman Gazetesi'nin 28.sayısından itibaren her sayının ikinci paragrafında "Umumi Lisan-1 Edebi (Genel edebi dil)" başlığı altında şu satırları yerleştiriyordu (Devlet, 2011: 92-93).

“Vilayet (Rusya'daki Türk) şivelerinde yedi sekiz gazete zuhur ettiği (ortaya çıktığı) halde Tercüman'ın müşterisi ve okuyanları ardında (gerisinde) olduğundan milletimizin umumi lisan-1 edebi arzusu bulunduğu halde müsebbib (sebep) oldu. Binaenaleyh (dolayısıyla) "Tercüman" eski meslekinden (yolundan) k1l kadar ayrılmayıp açık ve anlayacağı gibi sade umum lisan (genel dil) ile Kaşgar'dan Han Kirman'a kadar olan umur-u edebiyesine (edebi işine, kuralına) hizmet edecektir..."(Devlet, 2011: 92-93).

İsmail Gaspıralı ve Tercüman Gazetesi bütün Türklerin anlayabileceği ortak bir dil konusuna büyük önem veriyordu. Ortak dil ile bütün Türkler anlaşabilecek ve daha güçlü bir millet olabileceklerdi. Şive ve lehçe farklılıklarının giderilmesi, ortak bir Türkçenin varlığı ile mümkün olacaktı. İsmail Gaspıralı ortak Türkçe idealini çıkardğı Tercüman Gazetesi ile başarmak istemişti.

İsmail Gaspıralı Türklerin bir bütün olduğuna inanıyordu. Onlara Tatar, Azeri, Başkırt, Özbek gibi isimler verilmesini doğru bulmuyor, bu isimlerin bölmek, parçalamak, ve dağıtmak amacıyla verildiğini savunuyordu. İsmail Gaspıralı ortak edebi bir dille kolaylıkla basılı edebiyat geliştirilebileceğine ve geniş kitlelere yayılabilen eğitim sisteminin kurulabileceğine inanıyordu. İsmail Gaspıralı'nın savunduğu dil konuşulduğu ve yazıldığı zaman İstanbul'daki hamal ve kayıkçı ile Şarki Türkistan'daki deve sürücüsü ve koyun çobanının da anlayabileceği bir dil idi. İsmail Gaspıralı Osmanlı Türkçesinde Arapça ve Farsça kelimelerin anlaşılırlığı zorlaştırmasından dolayı bunların yerine Kırım Türkçesi ile başka şivelerden aldığı kelimeleri bir araya getirerek yeni bir yazı dili oluşturmuş ve bu dili de Tercüman Gazetesinde kullanmıştır (Ekinci, 1997: 29-30).

Dilde, fikirde ve işte birlik ideali ile Gaspıralı, Türk halkları arasındaki lehçe farklılıklarının ortadan kaldırılması, bütün Türklerin ortak bir alfabeye geçmesini, Türkçe'nin Arapça ve Farsça kelimelerden arındırılmasını, modern bir devlet olarak Türklerin bağımsız yaşamasını istemiştir. Tercüman gazetesi de bu görüşleri dile getirmiş ve yaygınlık kazanmıştır (Uzun, http://www.ismailgaspirali.org/yazilar/tuzun.htm).

İsmail Gaspıralı, ortak etnik-milli ve dini temel üzerinde Rusya imaparatorluğu içinde yaşayan Müslüman Türklerin birlikte hareket etmesi ve reforma tabi tutularak modernleşme yoluyla maruz kaldıkları problemlere çözümler üretilebileceğine inanıyordu. Bu doğrultuda milli bir birlik ile toplumun modern temelde dönüşümü ve yeniden inşası Gaspıralı'nın programının parçalarını teşkil etmiştir (Kırımlı, 2010: 43).

O dönemin koşullarına bakıldığında Batının ilerlemesi ve gelişmesi Osmanlı imparatorluğu kadar diğer devletlerin hakimiyeti altında yaşayan milletleri de etkiledi. Gaspıralı, batılı tarzda bir modernleşme ile Kırım Tatar Türklerinin milli ve medeni bir 
uyanışa geçmesini istemekte idi. Tercüman Gazetesi ile de bu amacını gerçekleştirmeyi planlamakta idi.

Tercüman Gazetesi'nin 11 Ağustos 1896 tarihli 31-1 sayısında şu ifadelere yer verilmiştir.

“Şive-i Osmaniyeyi sadeleştirmek lisan-1 Türki'yi ilerletmek mes'elesinin ehemmiyet-i edebiyesinden ma'ada daha büyük ehemmiyet-i siyasiyesi vardır. Yazının yalnız güzelliği aranılmamak daha ziyade "umumi"li matlap edilmelidir... En eski Osmanlı olan Türklerden ma'ada devlet-i Osmaniyeye tabi' bunca akvam-1 sa'ire vardır ki bunların lisan-ı hakimeyi tahsilleri farzdır, halbuki bu farzın edası için uzun senelerce Arabistan çöllerinde ve İran gül bağçelerinde dolanmak lazım olur ise iş bozulur..."(Yaman, 2002: 74).

Bu yazıda Osmanlı dilinin sadeleşmesinin öneminin yanında tüm Türkler arasında ortak bir dil olmasının çok daha önem arz ettiği vurgulanmıştır. Yazının biçiminden ziyade bütün Türkler arasında kabulünün çok daha önemli olduğuna işaret edilmiştir.

“Tercüman dönemini şekillendiren Gaspıralı İsmail Bey, yazılarında mahalli Tatar sözlerini ve deyimlerini de kullanmakla birlikte imlası ve ifade dünyasıyla sade bir İstanbul Türkçesini tercih etmiştir. Bu dönemde bir irfan ve bilgi kaynağ $\breve{l}_{1}$ olarak Rus ve Şark klasikleri Kırım Tatar Türkçesine aktarılarak ya Tercüman Gazetesinde tefrike edilmiş veya kitap olarak yayımlanmıştır. Rusçanın etkisi ve sosyal hayattaki ağırlığ1 arttığ1 için Kırım Tatar Türkçesi-Rusça sözlükler hazırlanmıştır"(Özkan, 2008: 531).

İsmail Gaspıralı Tercüman Gazetesinde Rus ve doğu ülkelerinden klasik eserlerin çevrilerek yayımlanmasını da sağlamıştır. Gaspıralı tercih ettiği sade İstanbul Türkçesiyle birlikte yerel Tatar deyimlerini de kullanmıştır. Böylece halkı da düşünerek yazılar yazmıştır.

Ancak bütün Türklere has ortak edebi dil yaratma gayretleri gerçekleşmedi. Bunun sebepleri arasında başta Rusya'da Türk mektep ve medreselerinde ortak bir müfredat yoktu ve buralarda Tecüman'ın dili ile eğitim verilemiyordu. Çarlık hükümeti Türkler arasındaki dil konusundaki tartışmalara fazla müdahele etmedi. Fakat Bolşevik hükümeti her bir Türk boyuna kendi lehçe ve şivesini geliştirme imkânı verdi ve böylece Gaspıralı'nın ortak edebi dil yaratma çabası sonuç vermedi (Devlet, 2011: 98).

\section{TERCÜMAN GAZETESI'NDE YER ALAN BAZI YAZI ve MAKALELERDEN ÖRNEKLER}

1896 senesi Mart ayı 31 numaralı 13. Nüshada "Ebuzziya Tevfik Bey" başlı̆̆ıyla ilgili yazıdan bir parça:

“Tevfik Beyin, lisanına ve tarzı ifadesine gelince, güzeldir; fakat, lazım derece sade değildir. Ahmet Mithat Efendinin ve Şemsettin Sami Beyin lisanı daha ziyade Türkçedir, binaenaleyh daha ziyade kavmi ve umumidir (Seydahmet, 1996: 82). 
Bu yazıda İsmail Gaspıralı'nın dile verdiği önem vurgulanmaktadır. Gaspıralı, Tevfik Bey'in dilini eleştiriyor ve daha sade olması gerektiğini düşünüyor. Ahmet Mithat ve Şemsettin Sami Bey'in dilleri Türkçe olduğu için daha anlaşlır buluyor ve sade bir Türkçe‘nin Türkler arasında daha anlaşılır bir dil olacağını savunmaktadır.

Tercüman Gazetesi'nin 1896 senesi Mart ayı 31 numaralı 14. Nüshasında

“ İşte Haber Bu Haber"... Diye Müslüman kızlarının tahsil ve terbiyelerine mahsus büyük mektebi fenniye ve edebiye verildiği " üzerine haberlerde meşhur tüccar ve fabrikatör Hacı Zeynelabidin Tagiyef önderliğinde Bakü'de asil kişilerden 150.000 ruble toplandığından bahsedilmiştir(Seydahmet, 1996: 84).

Tercüman Gazetesi'ndeki bu haber kız çocuklarının eğitimine verilen önemi vurgulamaktadır. Kız çocuklarının eğitimi için hayırsever zengin kişiler de yardımda bulunarak İsmail Gaspıralı'nın yolundan gitmişlerdir. Rusya Müslümanlarının medeni seviyelerinin yükselmesinde özellikle zengin kişilerin katkısı olmuştur. Ahmet ve Gani Baylar gibi hayırsever kişiler yaptıkları yardımlar ile eğitime büyük katkı sağlamışlardır. Kız çocuklarına okuma yazma öğretiminin yasak olduğu dönemleri düşünürsek ne kadar ilerleme kaydedildiği ortadadır. İsmail Gaspıralı'nın bin bir zorlukla çıkardığı Tercüman Gazetesi için yardım yapmayı reddeden zengin kimseler de bulunuyordu.

İsmail Gaspıralı, Tercüman'daki “Bizim Hal ve Maişet” adlı makalesinde yeni fikirlerle eski fikirleri, şu cümlelerle anlatır:

“Umumiyet ve ekseriyet üzere görenek esiri muhafazakâr (konservatör) olan ahâliden terakki ve 1slahat muhibleri (liberaller) ayrılıp, eşya ve ahvâle bakış ve dünyadan istek ve matlab cihetlerinde birbirlerinden tefrik oldular. Bunlardan terakki ve islahat isteyenlere "yeni fikirli", istemeyenlere "eski fikirli" denmektedir"(Yaman, 2002: 91-92).

Tercüman'ın bu ifadeleri eski ve yeni fikirli kimseleri birbirinden ayırmaktadır. İki grubun dünyaya bakışlarının farklı olduğunu yenilik isteyenlere yeni fikirli, istemeyenlere eski fikirli denmektedir. Bu sözlerden tutucu kesimin yeniliklere karşı geldiği ve sabit fikirli oldukları ortaya çıkmaktadır. Köhne düşüncelerde takılı kalmış kesim yenilikleri benimsememekle Avrupa tarzı medeni seviyeye ve yaşam biçiminin benimsenmesine engel teşkil etmişlerdir.

Tercüman Gazetesinde nadir olarak coşkun milliyetçi yazılara da yer verilmekteydi. İsmail Gaspıralı'nın “Var Olsun Türk” başlıklı makalesinde şu satırlar bulunuyordu:

“Biz Türklerin kabul-ü İslam'dan mukaddem ( İslam'ı kabul etmeden de önce ) milli yazılarımız vardı. Kabul-ü İslamdan sonra ilim ve edebiyat meyanında birçok hizmetlerimiz görüldü. Bunlar istidat-1 medeniyetimizin nişaneleridir (uygarlığa yatkınlığımızın işaretidir). Var idik, var olacağız."(Devlet, 2011: 109).

Tercüman Gazetesinin 1896 tarihli 46 numaralı "Ahvali Devleti Aliyei Osmaniye makalesinden: 
“Devleti Aliyede ıslahat ilan olunuyor. Fakat icrasız kalıyormuş. Bu ıslahatın ne demek olduğu fikredilsin: İster tarihe, ister evrakı mevkutaya müracaat edin, şimdiye kadar Avrupa'nın sslahat dediği yalnız ahaliyi hıristiyaniyeyi gözetmekten ibaret bulunmuştur. Halbuki devletin mayası ve ekser ahalisi ehli İslam'dır. Terakkii ticaret dedikleri ise ecnebi sermayesine ve teşebbüsatına meydan ve yol verdirmekten ibaret bulunmuştur. Bu halde mahalli ticaretin ve yerlinin terakkisinin cüz'i olacağ1 elbette tabiidir....̇̇dare muntazam değilmiş. Evet, nisbeten böyledir ve böyle olmamak ta mümkün değildir. Çünkü ta geçmiş vakitlerden kalma "Kapitülasyon" bağları ve zincirleri çözüldükçe intizama meydan kalmıyor... Gaflet devrinde aktedilmiş muahedelerle Türkiye'nin eli ayağı bağlanmış, misafir olarak kabul olunanlar haneye sahiplik hukukunu almışlardı. Avrupa memaliki Osmaniyeye "Hasta" namını veriyor. Hayır hasta değildir, bağlıdır, bir çözülsün de görsün, nasıl güzel yoldaş olur!"(Seydahmet, 1996: 164-165).

Makaleden Avrupa'nın 1slahat dediği sadece Hıristiyan halkı gözetmek amacında olduğu, Müslüman halkı gözetmenin olmadığı, ticaretteki gelişmelerin ise sadece yabancı sermayenin yolunu açtığı, yerli sermayenin geri planda kaldığı, Avrupa'nın Osmanlı Devletine hasta ismini verdiği, aslında hasta olmadığı bağımlı olduğu, kapitülasyonların da ülke için zararlı olduğu vurgulanmıştır.

Tercüman Gazetesinin "Yüzyıl” başlıklı yazısında Kırım ile ilgili şu ifadelere yer verilmiştir:

“April (Nisan) sekizde-Kırım'ın Rusya devletine koşulduğuna (katılmasına) yüz yıl oluyor...Tam yüz yıl burun (evvel)- 1783 senesi April sekizde kan dökümler ile naçarlanıp (kötüleşip) nizamsızlık ve baskınlar ile perişanlaşmış ufacık hanlık alemin en büyük devletine koşulup güçlü hükümet ve adil kanunlar ile kurcalanıp (çevrilerek) rahatı bulmuştur. $\mathrm{O}$ gün cümle Rusyalıların kıvançlı ve ferahlı günü olmuştur ki, Kırım Rusya'ya koşulmasıyla (katılmasıyla) memalik-i cenubiyede ve şarkiyede (güney ve doğu ülkelerinde) nüfusça çok terakki eylemiştir (gelişmiştir)..."(Devlet, 2011: 77).

İfadelerden de anlaşılacağı üzere İsmail Gaspıralı Kırım'ın ve onun Türk halkının Rusya'ya katıldığını, bunun halkın kendi isteği doğrultusunda gerçekleştiği ve bundan halkın yararlandığı gibi ifadeler kullanmak zorunda kalmıştır. Bu ifadelerden Gaspıralı'nın Çarlık hükümeti ile çatışmaya düşmek istemediğini anlıyoruz. Gerçekte Kırım işgal sonucu Rusya'ya katılmıştır ve Kırım halkı bağımsızlığından vazgeçmek zorunda kalmıştır. Gaspıralı gerçeği yazsa idi Tercüman Gazetesi Rus Hükümeti tarafından kapatılabilirdi.

28 Nisan 1908 tarihli 32 numaralı Tercüman Gazetesinde yayımlanan “Makedonya Meselesi Neden İbaret ?” makalesinden:

"Bundan böyle cins ve kavim itibarile Makedonya pek karışık bulunuyor. Makedonya'da Bulgarlardan maada Rumlar, yani Yunanlılar, Sirplar ve kısmen Ulah ile Arnavutlar hak talep ediyorlar. Sukut eden yalnız Türklerdir. Bulgarların 1slahat, muhtariyeti idare diye talep ettikleri şeylerden ahir matlapları Makedonya'yı Bulgaristan'a tutmaktır. Sırplar ve Yunanlılar bunun için Bulgarlara mukabelede 
bulunup on seneden beri vuruşmakta ve dalaşmakta bulunuyorlar. Avrupa hükümetlerinin müdahelesi de Makedonya'nın ıslahından ileri gelmiyor. Çünkü Avupa'nın metalibi islahat olsaydı "Islahatı umumiye'den bahsolunurdu. Makendonya sakızı çğneyip durmazdı”(Seydahmet, 1996: 166-167).

Makedonya'da Bulgarlar, Rumlar, Sirplar, Arnavutlar hak talep ederken sadece Türklerin sessiz kaldığı, Makedonya Osmanlı idaresinden çıktıktan sonra diğer milletlerin Müslümanları göçe zorladıkları, Müslümanların topraklarına göz dikip onları Osmanlı tarafına göçe zorlamalarıyla ilgili bir makaledir.

1896 senesi 14 Temmuz tarihli Tercüman'da yazılan Girit meselesine dair "Hakikati Hal” makalesinden:

“Şark işlerine bitarafen nazar edenlere kapalı değildir ki şarkın ahali Hristiyaniyesi beyninde zuhur edegelen fesatlar bunların istiklal arzusile hissiyatı diniyelerinden istifadeye çalışan dahili ve harici entrikacıların saylerinin semeresidir. Ya hissiyatı kavmiye üzerine kurulan fesat zuhur ettiğinde gazeteler ve telgraflarla aleme yaygara edildikten, şu mahalli fesatta ikamet eden "Türklerin" ve "mutaassipları" bundan haberleri bile olmuyor. Bu saf ve sade adamları alemi medeniyete birer kanlı vahşi sıfatında gösteren muharrirler büyük alçaklık ediyorlar! Anadolu'da, Rumeli'de, Türk vardır. Farzedelim ki bunlar vatandaşları olan Hristiyanlar aleyhinde (değil ya) bulunsunlar. Fakat Girit işlerinde "Türk fenalı̆̆ı", "Türk taassubu" nerede görüldü ve kim gördü ki, her yazdıklarını teftiş ve mülahazaya borçlu olan ehli kalem bunları Türklere isnattan geri durmuyor...."(Seydahmet, 1996: 165).

Girit meselesi üzerine yazılan bu makalede Hristiyan halkı kullanarak kışkırtan entrikacıların bulunduğu, Türk halkının dünyaya vahşet yapanlar olarak yanlış aktarıldığı, Osmanlı hükümetinin bunlara rağmen bu kişileri affettiği, ancak bu kışkırtıcıların karakola ateş açtığı on kişiyi öldürdüğünden bahsedilmiştir.

\section{TERCÜMAN GAZETESI'NINN EĞİTIME VERDİĞİ ÖNEM}

İsmail Gaspıralı ortak Türkçe ile bütün Türklerin anlayabileceği bir ortak dil meselesi üzerine çok gayret sarfetmiştir. Ayrıca okuma yazmayı daha kolay hale getirecek usul-u savtiye yöntemini benimsemiş ve bu yöntem ile eğitim verilmesi konusunda çokça çabaları olmuştur. Tercüman Gazetesi'nde de eğitim ile ilgili meseleler yer almıştır. İsmail Gaspıralı eğitim ile ilgili şu ifadeleri paylaşır:

“Tercüman ile efkar-1 umumiye hayli tahrik ve yeni usul ile kırk gün zarfında mübtedi çocuğa Türkçe okuyup yazmak öğretmek mümkün olduğu ilan olunarak Bahçesaray'ın "Kaytmaz A ğa" mahallesinin harabe mekteb binası biraz tamir ettirildi. Ve talebeden Bekir Efendi emekdar davet olunarak usul-i savtiyye ve didaktik ile pedogojinin en elzem cihetleri bu efendiye talim ettirilip “Birinci Muallim” tedarik olundu. Böylece tertip ettiğim program üzere 1884'te "Birinci Mekteb-i Cedidi" açmış oldum. Okunacak elifba yazdığım "Hıvace-i Sıbyan"idi. Müddeti tahsil üç sene; program-Türkçe okuyup yazmak, kıra'et-i Kur'an, İlm-i hal, hüsn-i hat, sarf-1 Türki, 
hizni hesab, imal-i Erbaa, tarih-i İslam ile coğrafya'dan tarihden ve hifz-1 sihhatten pek sade pek mutasar malumat vermekten ibaret idi"(Ekinci, 1997: 72).

Bu satırlardan Tercüman Gazetesinde yeni yöntem olan usulu-i savtiye ile bir çocuğun kırk günde okuyup yazabileceği, eski bir mektebin yeniden tamir ettirilip buraya öğretmen atanıp eğitime hazır hale getirildiği, eğitim süresinin üç yıl olduğu, dilin Türkçe, Kur'an öğretimi, İslam Tarihi, coğrafya gibi derslerin okutulduğunu anlaşılmaktadır.

İsmail Gaspıralı'nın Tercüman Gazetesi'nin eğitim öğretime verdiği önem ve etkisini şu sözlerle dile getirir:

“Tercüman'ın tesiri ile usul-ü savtiyye muallimliği öğrenmek için Kaskasya'dan ve Rusya'dan içlerinden Bahçesaray'a talebe ve molla gelmeye başladı. Birinci numune mektebi, hem mekteb hem de bir dereceye kadar "Darul-Muallim" vazifesini ifa ediyordu. Gelen mollalar bir iki ay mektebde misafir kalarak muallimlik şehadetnamesi alıyor ve memleketlerine dönüyorlardı. Böylece maarif ve teceddüd kıvılcımları öteye beriye sıçrıyordu"(Ekinci, 1997: 73).

Bu satırlar Tercüman Gazetesi'nin yeni öğrenme yöntemini tanıtarak diğer memleketlerden öğrenci ve öğretmenlerin gelmesini sağladığını ve okulların bu gelen kişiler için hem okul hem de öğretmen okulu olduğunu böylece yeni eğitim anlayışının yayıldığını, yeni öğrencilerin ve öğretmenlerin yetiştirildiği bir eğitim reformunun benimsenerek yaygınlaştığı bir atmosferin varlığını görmekteyiz.

Vecihi Sefa Fuat Hekimoğlu İsmail Bey Gaspıralı ve Türk Birliği ideali isimli makalesinde Türk dünyasında kadının statüsünü yükseltmek için çalışan Gaspıralı'nın en büyük hizmetinin, eğitimde giriştiği modernleşme hareketi olduğu, bu konudaki fikirlerini Tercüman vasıtasıyla yayıldığı vurgulanmıştır. İsmail Gaspıralı kadının iş hayatında aktif rol oynaması gerektiği düşünüyordu. Bu faaliyetlerle ilgili Tercüman gazetesinde başarılı kadınlarla ilgili haberlere yer verilerek başarılı kadınlar övülüyordu (Hekimoğlu, 2009).

“Tercüman gazetesinde "Milli Mektep Destesi" (27 Avgust 1910 / 12 Ramazan 1318, Sayı: 35) adlı bir yazıda da maarif idaresince mekteplerde okutulmas1 kararlaştırılan kitaplar arasında Hoca-i Sıbyan'ın devamı olan Kıraat-ı Türkî yer almaktadır. İsmail Bey, Türkçe yazma ve okumanın önemini birçok yerde belirttiği gibi ele aldığımız bu eserin "talimat" [Resim II] bölümünde de izah etmiştir. Medreselerde yer alan ezbere dayalı eğitim-öğretim anlayışının Batı kaynaklı modern eğitim sistemi içerisinde yer almadığını gören Gaspıralı, öğrencilerin ilk önce kendi ana dillerinde okuyup yazmalarını ve ezberi sadece namaz sureleri için kullanmaları gerektiğini bu "talimat" ta dile getirmiş ve örneklendirmiştir. Bu talimatta ayrıca hem öğrencilerin hem de öğretmenin dersi nasıl işleyeceği tarif edilmiştir. Derste karşılaşılacak herhangi bir problem dahi düşünülerek öğrencilere ve öğretmenlere tavsiyelerde bulunulmuştur"(Özkaya, 2011: 79-86).

İsmail Gaspıralı Tercüman Gazetesinde, ezberci eğitim yerine batı tarzı anadilde eğitimin önemini, derslerin işlenmesiyle ilgili öğretmen ve öğrencilerin nasıl 
bir yol izlemeleri gerektiği ile ilgili kitaplardan da yazılara yer vererek Tercüman Gazetesi'nin eğitim-öğretim konularına nasıl yaklaştığını ve eğitime verilen önemini görmekteyiz.

\section{SONUÇ}

Tercüman Gazetesi Rusya Türklerinin Müslümanlarının milli ve medeni seviyelere ulaşması açısından yol gösterici olmuştur. İsmail Gaspıralı bütün bu zorluklara rağmen Tercüman Gazetesini diğer gazeteler de göz önünde bulundurulduğunda uzun bir dönem boyunca yayın hayatında kalmasını sağlamıştır. Özellikle eğitim konusunda halkı aydınlatan Tercüman Gazetesi İsmail Gaspıralı'nın Usul-i Cedit Hareketinin savunucusu olmuştur.

İsmail Gaspıralının kadınlara ve kız çocuklarına verdiği önem de gazetede neşredilen haber ve yazılarda görülmektedir. Dikkatli bir üslupla yazılan yazılar halkı kışkırtır nitelikte olmayıp üstü kapalı bir üslupla halkı aydınlatarak Batı ve Avrupa tarzı yeniliklere halkı açı hale getirerek bilinçlendirmeyi sağlamıştır. Tüm Türkleri birleştirmek amacıyla ortak bir Türkçe ile eğitim öğretimin yapılması için çaba sarf eden İsmail Gaspıralı, Tercüman Gazetesi'yle de bu ülküsünü dile getirmiştir. Eğitime maddi destek verilmesi için yardım kuruluşlarının olması gerektiğiyle ilgili haberler de Tercüman'da yer almıştır. Özelikle zengin kişilerin yardımı Tercüman Gazetesi'nin neşrini ve devamını sağlamıştır.

Sonuç olarak Tercüman Gazetesi o dönemin şartları düşünüldüğünde halkın bilinçlenmesi ve medeni seviyeye ulaşması konusunda rehber olmuştur. Tercüman Gazetesi izlediği denge politikası ve tavrı ile Rus Hükümetini karşısına almayarak uzun süre yayın hayatında kalarak halkı bilinçlendirme gayretinde olmuştur. İçeriği ve konuları ile halkı bilinçlendirerek milli uyanışı sağlamaya çalışmıştır. Özellikle kadın hakları ve eğitimi konusunda da halkı bilinçlendirerek kadınların günlük yaşamda ve iş dünyasında yer alması gerektiğiyle ilgili mücadele etmiştir. Tercüman Gazetesi, Rusya ve diğer Müslüman Türk halkının ufkunu genişletmiş ileri bir medeniyet seviyesine ulaşmalarına öncülük etmiştir.

\section{KAYNAKÇA}

Caferoğlu, A. (1933). İsmail Bey Gasprinski, Azerbaycan Yurt Bilgisi, İstanbul, cilt 2, s.167

Devlet, N. (1999). Rusya Türklerinin Milli Mücadele Tarihi. Ankara: AKDTYK Türk Tarih Kurumu Yayınları.

Devlet, N. (2011). İsmail Gaspıralı: Unutturulan Türkçü İslamcı Modernist. İstanbul: Başlık Yayın Grubu.

Ekinci, Y. (1997). Gaspıralı İsmail. Ankara: Ocak Yayınları.

Fisher, A. (2009). Kırım Tatarları. (E. B. Özbilen, Çev.). İstanbul: Selenge Yayınları.

Georgeon, F. (2005). Türk Milliyetçiliğinin Kökenleri, Yusuf Akçura (1876-1935), 4. Bs, (A. Er çev.). İstanbul: Tarih Vakfı.

Hablemitoğlu, N. (2006). Gaspralı İsmail. İstanbul: Bir Harf Yayıncılık. 
Hekimoğlu, V. S. F.(2009). İsmail Bey Gaspıralı ve Türk Birliği, History Studies,1/1, 297-317. 31 Mayis 2013 tarihinde http://www.historystudies.net/Makaleler/1070159866_12Vecihi\%20Sefa\%20Fuat\%20HE $\mathrm{K} \% \mathrm{C} 4 \% \mathrm{~B} 0 \mathrm{MO} \% \mathrm{C} 4 \% 9 \mathrm{ELU}$.pdf adresinden erişildi.

Kalsın, B. (2014). İsmail Gaspıralı ve Tercüman Gazetesi, Uluslararası Hakemli İletişim ve Edebiyat Araştırmaları Dergisi, Jel Kodu: Z19, 2(2): 95-115.

Kırıml, H. (2010). Kırım Tatarlarında Milli Kimlik ve Milli Hareketler, 2. Bs. Ankara: Türk Tarih Kurumu Basımevi.

Özkan, N. (2008). Kırım Tatar Türkçesinin Yayılma Alanları, Turkish Studies, 3/7, 524-554. 30 Mayis 2013 tarihinde http://turkishstudies.net/sayilar/sayi13/29ozkannevzat.pdf adresinden erişildi.

Özkaya, Y. (2011). İsmail Gaspıralı'nın Kıraat-ı Türki Adlı Eseri, Türkbilig, /22 :79-86.

Seydahmet, K. C. (1996). Gaspıralı İsmail Bey. İstanbul: Akasya Bir Vakfı Yayınları.

Turhan, K. (2013). Dilde, Fikirde ve İşte Birlik. İstanbul: Doğu Kitabevi.

Uzun, T. (t.y). İlk Türk Aydınlanma Hareketi: Ceditcilik ve İsmail Gaspıralı, 03 Temmuz 2018 tarihinde http://www.ismailgaspirali.org/yazilar/tuzun.htm adresinden erişildi.

Yaman, E. (2002). İsmail Gaspıralı ve Ortak Türkçe. Ankara: Alternatif Yayınları. 